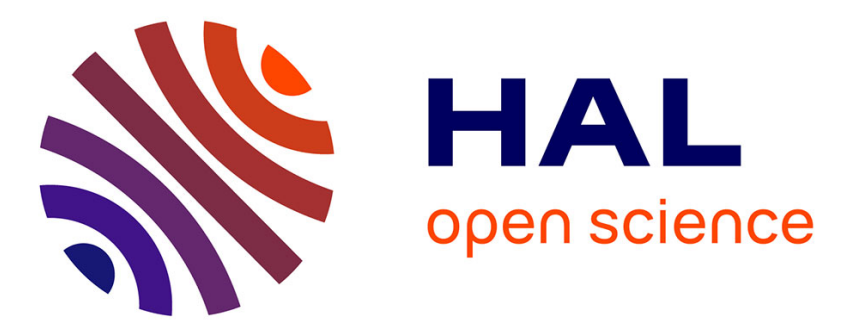

\title{
Innovation and international technology transfer: The case of the Chinese photovoltaic industry
}

\author{
Arnaud de La Tour, Matthieu Glachant, Yann Ménière
}

\section{To cite this version:}

Arnaud de La Tour, Matthieu Glachant, Yann Ménière. Innovation and international technology transfer: The case of the Chinese photovoltaic industry. Energy Policy, 2011, 39 (2), pp.761-770. 10.1016/j.enpol.2010.10.050 . hal-00498578

\section{HAL Id: hal-00498578}

https://hal-mines-paristech.archives-ouvertes.fr/hal-00498578

Submitted on 7 Jul 2010

HAL is a multi-disciplinary open access archive for the deposit and dissemination of scientific research documents, whether they are published or not. The documents may come from teaching and research institutions in France or abroad, or from public or private research centers.
L'archive ouverte pluridisciplinaire HAL, est destinée au dépôt et à la diffusion de documents scientifiques de niveau recherche, publiés ou non, émanant des établissements d'enseignement et de recherche français ou étrangers, des laboratoires publics ou privés. 
Tél. : 33 (1) 40519000

July 2010 


\title{
Innovation and international technology transfer: The case of the Chinese photovoltaic industry
}

\author{
Arnaud de la Tour, Matthieu Glachant, Yann Ménière \\ April 2010
}

\begin{abstract}
China is the largest solar photovoltaic cell producer in the world, with more than one third of worldwide production in 2008, exporting more than 95 percent of what it produces. The purpose of this paper is to understand the drivers of this success and its limits, with a particular emphasis on the role of technology transfers and innovation. Our analysis combines a review of international patent data at a detailed technology level with field interviews of ten Chinese PV companies. We show that Chinese producers have acquired the technologies and skills necessary to produce PV products through two main channels: the purchasing of manufacturing equipment in a competitive international market and the recruitment of skilled executives from the Chinese diaspora who built pioneer PV firms. The success of these firms in their market is, however, not reflected in their performance in terms of innovation. Rather, patent data rather highlight a policy-driven effort to catch up in critical technological areas.
\end{abstract}

The authors would like to thank the Agence Française de Développement which supported this study, and all the people they interviewed and who contributed to this work. 


\section{Introduction}

There is a large consensus in the international community that effective mitigation of climate change will require the massive deployment of carbon-friendly technologies on a global scale ${ }^{i}$. Yet the very notion of technology diffusion remains a tricky issue in climate negotiations, as evidenced by the creation of a working group under the United Nations Framework Convention on Climate Change (UNFCCC) dedicated to this issue $\mathrm{e}^{\mathrm{ii}}$.

In international discussions, the precise scope of technology diffusion remains ambiguous. It refers to the deployment of technology-based solutions to reduce greenhouse gas (GHG) emissions, such as wind turbines, solar panels, and nuclear power plants. But it also alludes to the transfer of the technical knowledge required to produce these turbines, panels or plants by local firms in developing countries. The latter interpretation of transferring knowledge is favoured by developing countries, and explains their request in climate talks for relaxing intellectual property rights (IPR). Although the deployment of technological goods is what matters to address climate change, the transfer of technological capabilities is indeed the key to developing countries obtaining a share of the green business pie. From a general interest point of view, it also reduces costs through increased competition.

The case of the Chinese photovoltaic (PV) industry is particularly interesting in this respect. In 2009, the deployment of solar panels in China had hardly started. Yet with more than 35 percent of worldwide production capacity in 2008 (of which 98 percent was exported), the Chinese domestic industry is the world leader in the production of PV cells and modules. In a nutshell, China has succeeded in acquiring the technologies for producing solar PV, without deploying PV systems in its territory. This case suggests that technology deployment and the diffusion of production technology are two distinct issues.

The purpose of this paper is to understand the drivers and limitations of this Chinese success in mastering a production technology that had initially been developed in developed countries. More precisely, we will address questions such as: How did Chinese firms manage to acquire production technologies and skills? Have IPR impeded this process? Is China now able to produce new technologies domestically? The underlying goal of this case study is to derive policy lessons on how technology can diffuse successfully in emerging countries.

We combine both quantitative and qualitative evidence. On the quantitative side, we rely on a dataset comprising 79,642 PV-related patents to analyse cross-country innovation and technology transfers in the different segments of the PV industry. To supplement this quantitative analysis, 
we carried out a series of field interviews with PV actors in China ${ }^{\text {iii }}$. These interviews allowed us to further understand specific details of the economics of the Chinese PV industry, and provided qualitative information concerning the innovation and technology transfers to China.

Our analysis also draws on the available literature on the photovoltaic industry. This includes the works of Yanga et al. (2003) and Marigo (2007). We also exploit a substantial body of professional literature published by public organizations (European Commission PV status report 2003, 2005, 2008 and 2009; IEA, 2009; REDP, 2008), industry associations (EPIA, 2009, REN21, 2008) and consulting groups (McKinsey, 2008).

The paper is organized into four sections. In Section 1, we highlight the position of China in the global PV market. We then characterize and explain how technology transfer is occurring from developed countries to China in Section 2. Then, in Section 3, we focus on the innovation process in order to see whether China is now a major innovator. Section 4 presents our conclusions.

\section{The global PV industry}

This section yields an economic analysis of the PV sector in order to recast our understanding of the role of China in the rapid development of the PV industry on a global scale.

\subsection{The demand}

The large-scale deployment of PV generation capacity, and consequently the existence of a mass market for PV modules, is a very recent phenomenon. Until the late nineties, PV systems have been installed almost exclusively off of the grid, for marginal uses (communication devices, satellites, remote habitations) for which PV electricity was competitive compared to other available off-grid electricity sources. As illustrated in Figure 1, the photovoltaic market took off around 1997 and it has been growing exponentially since 2003. Over the 2003-2009 period, the average annual growth rate was $45 \%$. This acceleration is chiefly in industrialized countries, and mainly comprises on-grid installation. In 1996, 7.9\% of PV systems were installed on-grid; by 2007, it had reached $80 \%$ (REN21, 2008).

Figure 1 Photovoltaic installation per year from 1997 to 2009 


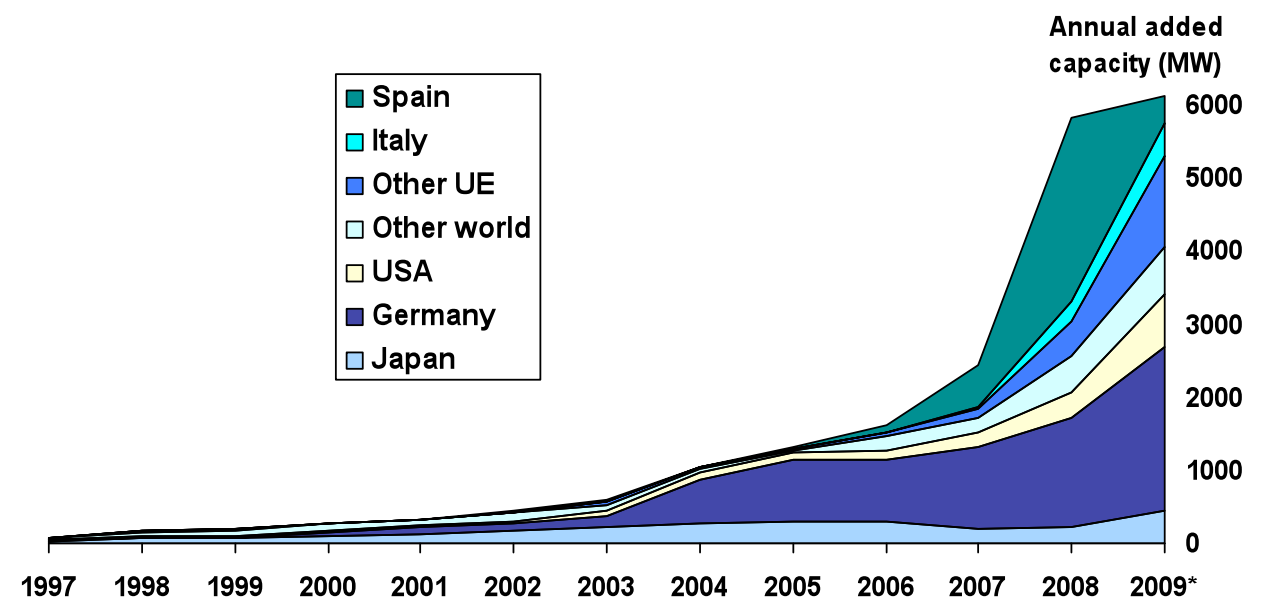

Source IEA, 2009 and EPIA, 2009. * forecasted.

This fast deployment of on-grid PV systems has been entirely driven by incentive policies initially implemented in a limited number of industrialized countries (mainly Germany, Japan, Spain, and the US). PV electricity cannot compete on the power grid because it is more expensive than traditional electricity sources. Therefore, the development of national markets requires economic incentives.

Besides various tax credits where the financial burden falls upon taxpayers, the main instrument aimed at stimulating the PV is the Feed-In Tariff (FIT). FITs consist of setting administrativelyfixed guaranteed prices at which electricity suppliers must purchase renewable electricity from producers. FITs have been used since 1994 in Japan and then introduced in Germany in 2000, inducing the healthy growth from 2000 shown by Figure 1. Spain also adopted a FIT in 2006 which was so generous that it led to a market boom in the country in 2008. Spanish authorities reacted in 2009 by setting a cap limiting the deployment of PV systems to $500 \mathrm{MW}$ per year. Along with the economic downturn, this policy change explains why the market growth slowed down in 2009.

The majority of developed countries have now implemented FITs. A notable exception is the US in which 29 states have opted instead for the use of Renewable Portfolio Standards (RPS). RPS are mandates requiring each utility to have a minimum percentage of power that is sold or produced be provided by renewable energy sources. That is, they prescribe a quantity, not a price as in the case of FIT. 
In contrast, policies promoting solar energy hardly exist in developing countries. Their priority is to find the cheapest source of energy to feed economic development, and therefore PV energy is mostly used in off-grid installations. In particular, China accounts for a very small share of the global PV demand (around 2.2\% in 2009, Source: EPIA 2010).

\subsection{The supply}

Figure 2 presents the PV supply chain. The industrial production process includes four technical stages that are briefly described in Box 1. Then the deployment of the PV system requires combining the modules with complementary equipment (such as batteries or inverters) into integrated systems which, once installed, can generate power. As explained in the introduction, we focus our analysis on the first four production stages, Silicon, Wafers/Ingots, PV Cells, and PV Modules. They account for $60 \%$ of the average global cost of installed PV systems in 2006.

\section{Figure 2 PV supply chain}

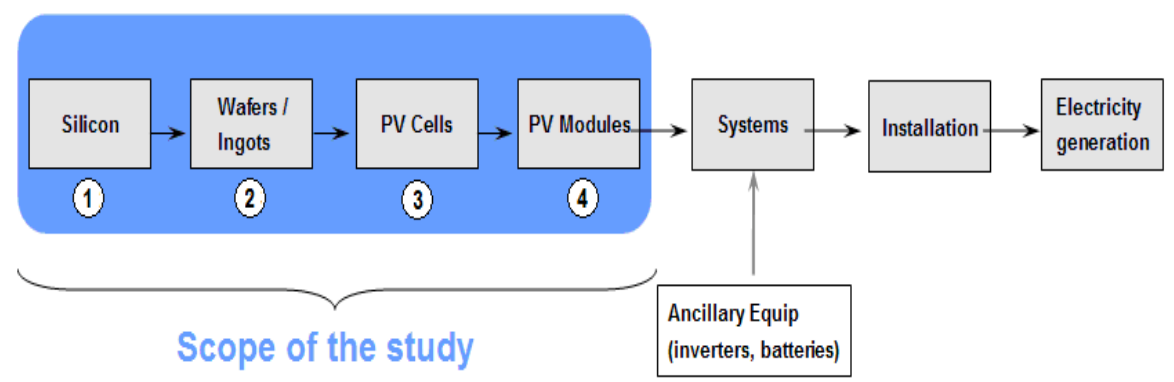

Source: Authors

\section{Box 1: The PV production process}

The production of PV modules involves four technical steps: 
1. Silicon purification from silica $(\mathrm{SiO} 2)$ found in quartz sand. The ultra high purity required for the photovoltaic industry ( $>99.999 \%$ pure) is obtained through heavy and highly energyconsuming chemical processes.

2. Ingot and wafer manufacturing. An ingot - a cylinder or a brick of silicon - is grown from the pure silicon. It can be a single crystal, called monocrystalline silicon or monosilicon, or multiple silicon crystals that are smaller; a material called polycrystalline silicon or polysilicon ${ }^{\mathrm{iv}}$. Then, using a saw, ingots are sliced into thin layers called wafers. Secondary processes like polishing are involved.

3. Cell production. To form the cell, two differently doped wafers are assembled together to form a so-called p-n junction responsible for the photovoltaic effect, and the top and rear metal contacts are applied. Many treatments or modifications in the process can be applied to increase the efficiency.

4. Module assembling. Cells are soldered together, the electrical junction being done by hand or automatically, and the cells are encapsulated in glass sheets to form a module which will be cooked in a laminating machine.

Table 1 shows the market share of Chinese producers in the different segments. In 2007, China was the world leader in cell production and module assembling (35\%). China is followed by the UE (29\%), Japan (18\%), and Taiwan (12\%). This is relatively new: in 2003, China's market in cell and module production share was only $1.6 \%$.

In contrast, its market share in upstream segments is much lower. China produced just $2.5 \%$ of the world's silicon in 2007 (Winegarner, 2009) while the US, Germany, and Japan account for more than $80 \%$. Chinese firms are however planning important capacity increases that will allow them to produce $15 \%$ of the world's silicon in 2010 (REDP, 2008). These projects are strongly supported by the Chinese government, as we will see later. The pattern is similar for ingots and wafers: China still represents a minor part of world production, but it is developing quickly, the annual average rate of increase in ingot production was more than $116 \%$ from 2004 to 2007 (REDP, 2008).

Table 1 China market share in different PV industry segments in 2007 


\begin{tabular}{|l|c|}
\hline Segment & China Market share \\
\hline Silicon & $2.5 \%$ \\
\hline Ingot and wafer & $<5 \%$ \\
\hline Cells & $27 \%$ \\
\hline Module & \\
\hline
\end{tabular}

Source: Ruoss, 2007, REDP 2008, authors' calculations

It is interesting to relate these patterns to the economic characteristics of the different segments presented in Table 2. China is strong in cell and module manufacturing, the most competitive segments, with the lowest concentration as shown by the Herfindahl-Hirschman Index (HHI) ${ }^{v}$, and where profitability is low compared to the more upstream segments.

Technological barriers to entry are relatively low in downstream segments, which have made possible the strong presence of Chinese firms in these segments. The cell production technology is easily accessible because, contrary to upstream segments, turnkey production lines can be bought and run without much prior experience in manufacturing cells. In this context, the relative low price of energy in China has spurred the creation of local firms in this energy intensive segment of the PV industry. Note that the size of investment costs in cell production has not prevented Chinese producers to enter the market. Module assembling is technologically simpler and it is labour-intensive, which gives Chinese firms a competitive advantage ${ }^{\mathrm{vi}}$. In contrast, silicon purification requires advanced technologies and very specific know-how to control all the parameters of the chemical reactions, in order to be able to produce silicon at a competitive price. We will examine technology issues at length in later sections.

Table 2 PV industry segments economic features in 2007

\begin{tabular}{|c|c|c|c|c|c|}
\hline Segment & $\begin{array}{c}\% \text { cost in a } \\
\text { panel }^{\mathrm{a}}\end{array}$ & $\begin{array}{c}\text { Market } \\
\text { concentration } \\
\text { (HHI) }\end{array}$ & $\begin{array}{c}\text { Investment } \\
\text { cost }^{\mathrm{b}} \\
\text { (millions/USD) }\end{array}$ & $\begin{array}{l}\text { Technological } \\
\text { barrier height }\end{array}$ & $\begin{array}{c}\% \text { of } \\
\text { profit }^{\mathrm{c}}\end{array}$ \\
\hline Silicon & $13 \%$ & 0.19 & 140 & High & $41 \%$ \\
\hline Ingot and wafer & $27 \%$ & 0.24 & 95 & Medium/High & $41 \%$ \\
\hline Cells & $27 \%$ & 0.04 & 125 & Medium/Low & $11 \%$ \\
\hline Module & $33 \%$ & $<0.04$ & 25 & Low & $7 \%$ \\
\hline
\end{tabular}

${ }^{a}$ Excluding the cost of ancillary equipments and the installation cost.

${ }^{b}$ Investment for a plant with an annual production capacity of 1,000 tonnes for silicon purification, and $100 \mathrm{MW}$ for the downstream segments.

$c \%$ of the whole profit along the supply chain

Sources: Ruoss, 2007, REDP 2008, adapted by the authors. 


\section{Technology transfers to China}

We have seen that China has strong positions in downstream segments, and has plans to increase its market share dramatically in more technology-intensive activities located upstream in the production chain. We show in this section that the rapid development of the Chinese PV industry has been made possible by the successful transfer of technologies form industrialized countries during the last decade. We discuss in decreasing order of importance the different channels through which the technology was introduced in China.

\subsection{The markets for manufacturing equipment}

From purified silicon to solar panels, products along the PV supply chain are very standardized. Market competitiveness mainly derives from the capability to manufacture products that satisfy a standard level of quality at an affordable cost. In this context, successful entry into each of the market segments requires access to state-of-the-art production technology. This in turn requires international markets for production equipment that is competitive.

The number of manufacturing equipment producers registered on ENF website serves as a proxy of competition intensity in the market for PV manufacturing equipment. Table 3 presents each PV industry segment in November $2009^{\text {vii }}$. The first line gives the total number of providers while the second gives only the number of firms which provide turnkey production lines.

There are a significant number of suppliers in each segment of the supply chain. However, the number is significantly higher in the downstream segments where Chinese firms have mostly entered the PV business, and thus the competition is fiercer. Downstream segments also present more suppliers offering integrated turnkey production lines that make it possible to start production with a minimum level of technical knowledge. By contrast, equipment suppliers are scarce in upstream segments, which is a factor in why Chinese companies have difficulties entering this segment. 
Table 3 Count of manufacturing equipment providers in the PV industry

\begin{tabular}{|ccccc|}
\hline All firms* & $\begin{array}{c}\text { Ingot } \\
70\end{array}$ & $\begin{array}{c}\text { Wafer } \\
178\end{array}$ & $\begin{array}{c}\text { Cell } \\
335\end{array}$ & $\begin{array}{c}\text { Module } \\
234\end{array}$ \\
\hline $\begin{array}{c}\text { Firms providing turnkey } \\
\text { production lines }\end{array}$ & 1 & 9 & 15 & 26 \\
\hline
\end{tabular}

* Firms selling specific equipment that are part of the production lines

Source: ENF website

Besides the importing of equipment goods, the purchase of manufacturing equipment usually involves the transfer of complementary know-how through training sessions of engineers and technicians operating the production line. This in turn progressively enables PV manufacturers to adapt their production chain to local conditions - for instance, substituting some equipment with a cheaper workforce. Several of our interviewees moreover indicated that large PV manufacturers tend to develop partnerships with equipment suppliers, sharing know-how and feedback to improve the manufacturing process. Although they may include temporary exclusivity clauses, such partnerships make it possible for equipment suppliers to redistribute this know-how to other customers, thereby accelerating the circulation of knowledge across the industry.

Another evidence of the diffusion of technology generated by the international trade of equipment goods is the progressive emergence of equipment goods suppliers that are solely Chinese. This is illustrated in Figure 3, which shows the nationality of manufacturing equipment suppliers in each of PV segment in 2009. Although almost no Chinese firms are able to produce turnkey production lines, there exist a significant number of Chinese firms selling specific equipment. This has important implications as it allows Chinese firms manufacturing PV products to buy cheaper production equipment, provided that they are able to customize their production line by integrating specific Chinese equipment. 
Figure 3 Countries shares in the number of equipment providers in each segment ${ }^{\text {viii }}$ (2009)

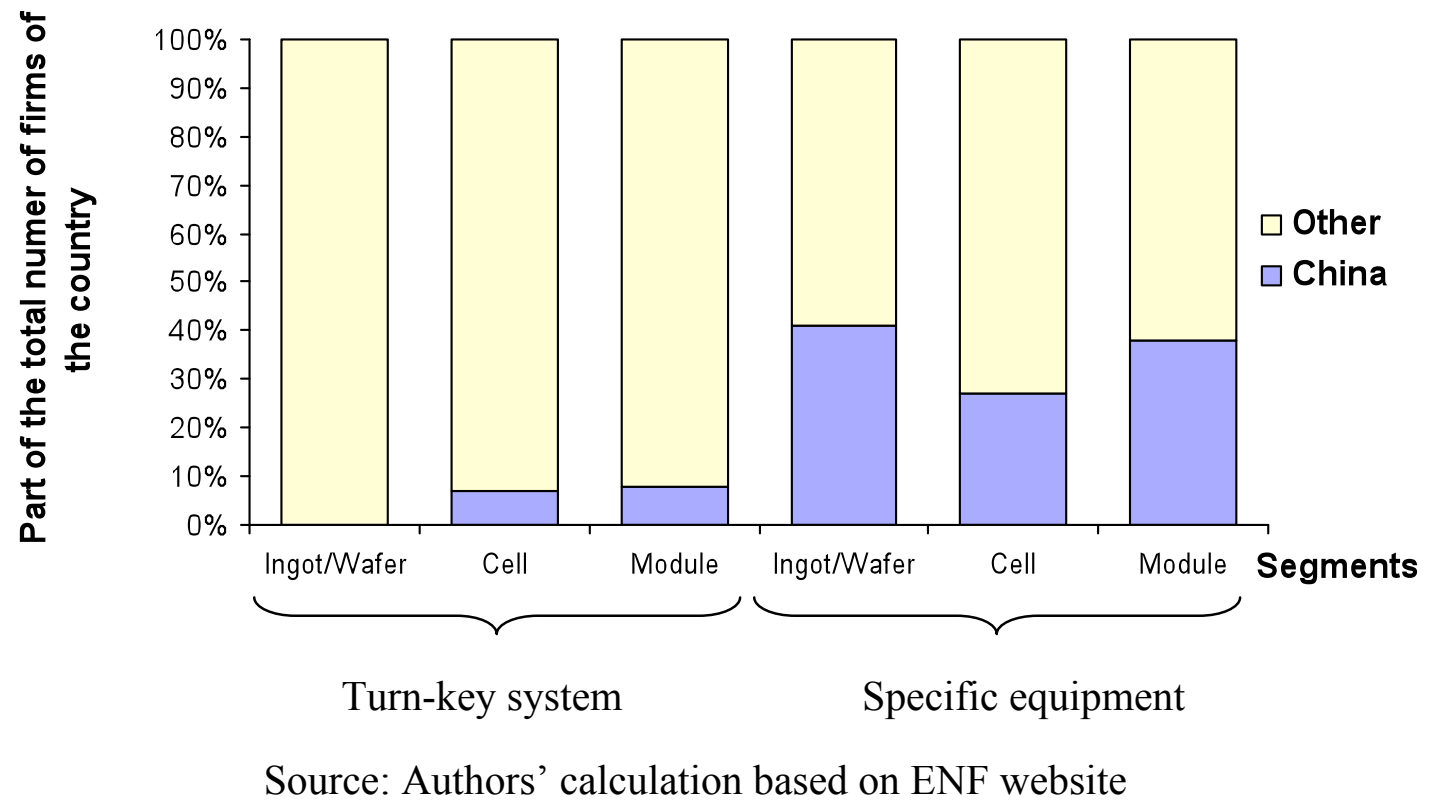

\subsection{Labour mobility}

The circulation of a skilled workforce has been another key factor aiding the emergence of the Chinese PV industry. Recall that a major part of the technology concerns the operation of manufacturing processes, which mainly consists of know-how. In this context, the manufacturing experience of skilled employees is a key asset.

Chinese PV companies have benefited strongly from the arrival of highly skilled executives, who brought capital, professional networks, and technology acquired in foreign companies or universities to China. For instance, the founder and CEO of Suntech, the China largest PV company, had been studying at the University of New South Whales in Australia, and then worked for the Australian company Pacific Solar. In addition, four out of the six members of the Suntech Board studied or worked in the US or in the UK. The CEO of the second largest company, Yingli, also studied abroad. In Trina Solar, half of the 12 person management team have studied or worked abroad: 4 in the US, 2 in Singapore. At Solarfun, the figure is 7 out of 10. On average, $61 \%$ of the board members of the three largest Chinese PV firms have studied or worked abroad $^{\mathrm{ix}}$. This highlights the importance of the Chinese Diaspora: 8 million Chinese people live in foreign industrialised countries (source: Overseas Compatriot Affairs Commission, R.O.C). 
To a large extent, this prevalence of executives with foreign training results from aggressive recruitment strategies pursued by Chinese firms in a context of scarce skilled labour locally. Suntech has a special program for recruiting foreign Chinese, while Trina Solar has created special "international staffing teams".

The local mobility of Chinese employees has also accelerated knowledge diffusion within China. Although the phenomenon is hard to quantify, representatives of three Chinese companies complained during our interviews about their employees being hired by other companies or creating their own company. Moreover, we also learnt that Chinese firms are developing specific programs to attract middle level management employees. There even exist agreements between the 9 biggest Chinese solar firms to prevent hiring each other's skilled employees.

\subsection{Foreign direct investment}

The economic literature has shown for a long time that investment by a multinational firm in a productive asset such as factory in a foreign country also induces a transfer of knowledge, since the technology is operated directly in the recipient country.

In 2009, China had attracted about one third of the global foreign direct investment (FDI) flows in the PV industry. Although massive, this is a rather recent phenomenon, which has not been a decisive factor in the emergence of the Chinese industry. Table 4 presents the top 9 PV manufacturers located in China. Only three of them feature investment links with foreign companies. Moreover, these FDI-based firms turn out to be late entrants, whose creation has followed in the footsteps of strictly Chinese pioneer firms.

Although it was not decisive for the emergence of Chinese pioneers, incoming FDI is nevertheless likely to accelerate technology transfers to China. Figure 4 moreover shows that the proportion of joint ventures with respect to fully owned subsidiaries is much more important in China than in other countries. This reflects a general feature of the Chinese economy, where public authorities often force foreign investors to accept joint ownership. Such joint ventures are likely to induce more knowledge spillovers than the creation of mere subsidiaries, because they involve a local partner. 
Table 4 Top 9 PV companies in China

\begin{tabular}{cccc} 
& Output (MWp) & Creation & FDI-Joint Venture links \\
\hline Suntech & 327 & 2001 & None \\
Yingli & 142 & 1998 & None \\
\hline JingAo & 113 & 2005 & Australia \\
Solarfun & 88 & 2004 & None \\
Sunenergy & 78 & 2004 & Australia \\
Canadian Solar & 55 & 2001 & Canada \\
Ningbo Solar & 45 & 2003 & None \\
Trina Solar & 37 & 1997 & None \\
Jiangsu Junxin & 35 & - & None
\end{tabular}

Source European Commission (2008 and 2009)

Figure 4 Regional repartition of the two types of FDI

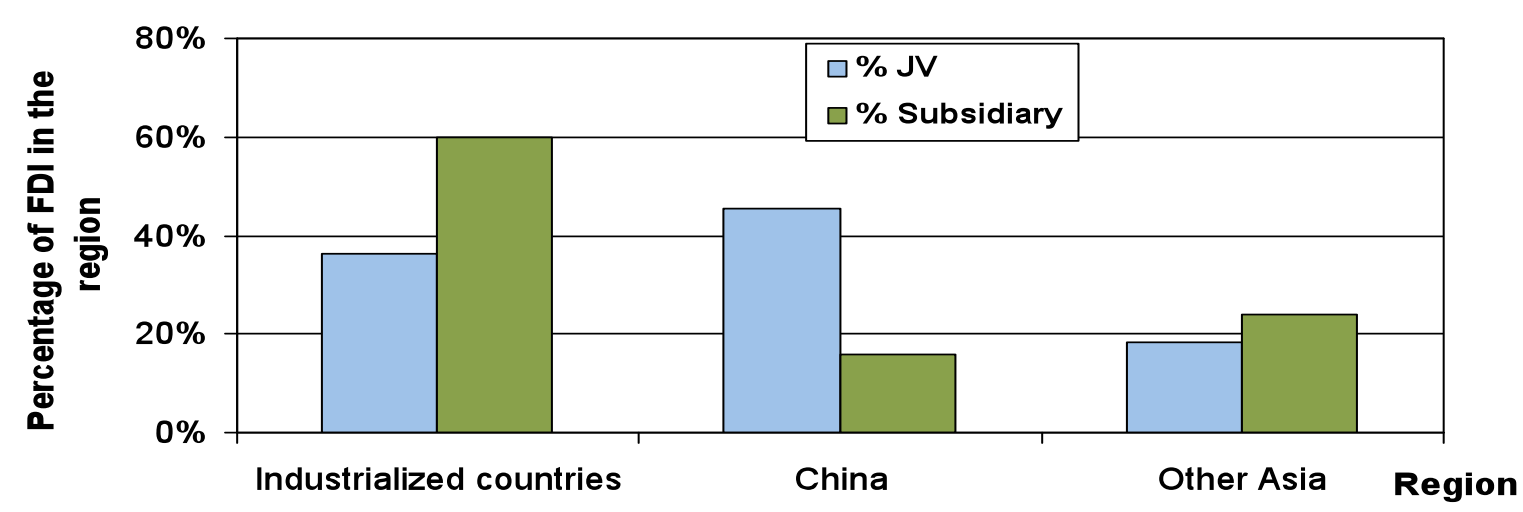

Source: Authors

\subsection{Licensing}

Another classical market channel of technology diffusion identified in the economic literature and the most self-evident - is licensing. But it has played no role in our story as licensing is almost inexistent the PV industry. We are aware of only one case: Germany's Johanna Solar Technology granted a license to the Chinese company Shandong Solar Technology in 2008 to build a production line. 


\section{Chinese innovation}

We have just seen that China has mainly acquired foreign technologies to create a domestic PV industry mostly through the international trade of manufacturing equipments and the hiring of top level managers trained in industrialized countries. In this section, we investigate whether China is now able to generate locally new technologies and inventions.

\subsection{A study of PV patents}

As a first measure of innovation in the PV industry, we tabulate patent applications ${ }^{\mathrm{x}}$. Although patents do not provide a measure of all innovation, they offer a good indication of innovative activity and allow for interesting cross-country comparisons. Data on patents were extracted and filtered from the espacenet website, a free online service developed by the European Patent Office for searching information on patents and patent applications, available at http://ep.espacenet.com. Using International Patent Classifications combined with key word searches, we created separate patent indicators for each segment of the PV supply chain. More information on our dataset is available in Appendice 2.

Figure 5 represents major countries' shares of innovation patented worldwide for each segment of the PV industry in 2006-2007. China's performance is impressive as it ranks third in all segments. But in silicon production it is all the more so, where it leads with $37 \%$ of world patents. Comparing these percentages with the market shares presented above in Table 1 leads again to distinguishing between upstream and downstream segments. China's patenting activity is significantly higher in silicon production, ingot and wafer manufacturing than its contribution to world production (respectively, 2.5 and 5\%). The reverse is true in downstream segments in which China is the second largest producer with a $27 \%$ market share (leader since 2008 with $35 \%$ ) whereas it generates around $15 \%$ of worldwide inventions. This suggests different roles for innovation in silicon production, ingot and wafer manufacturing on the one hand, and cell production and module assembling on the other. 
Figure 5 Percentage of world patented innovation by segment and country in 2006-2007

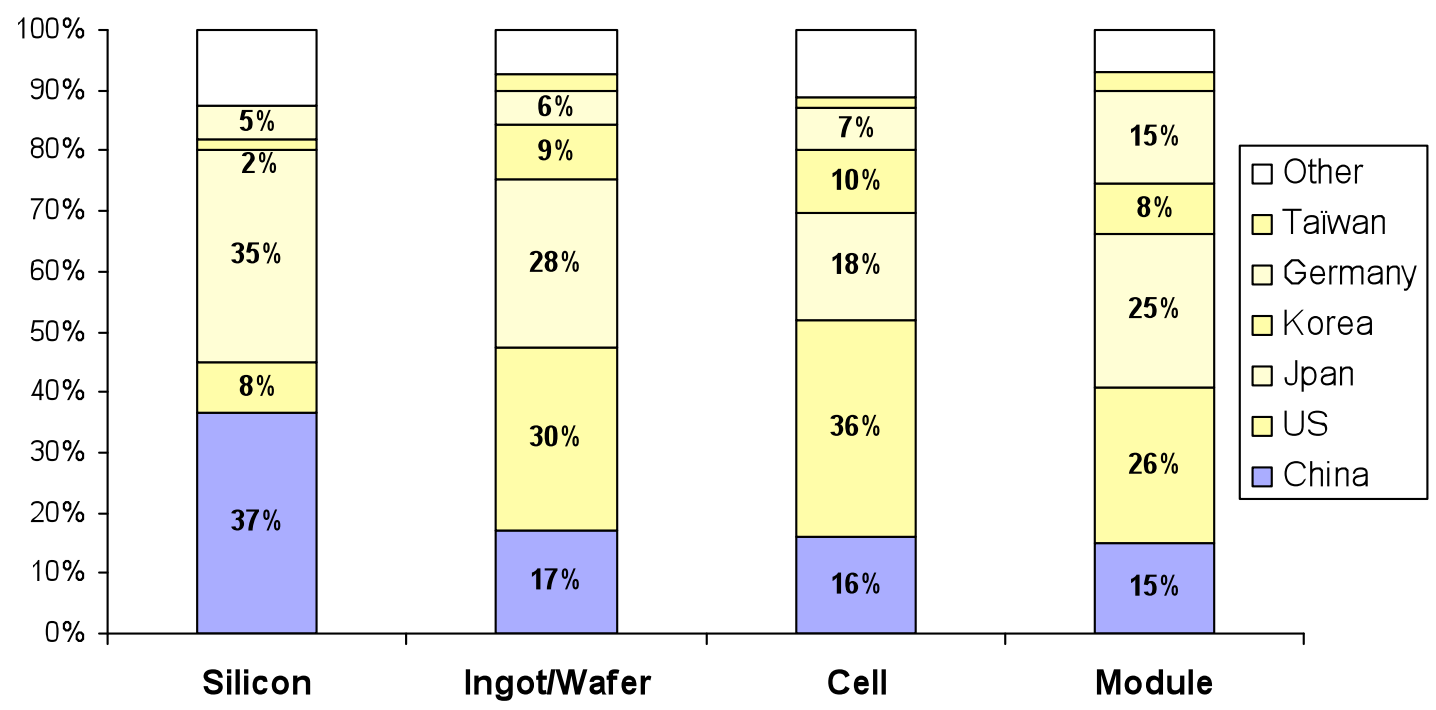

Source: Authors' calculations

\subsection{Innovation in cells and modules}

The important share of China in globally patented innovation has to be put in perspective. Indeed, only $1 \%$ of Chinese patents are also filed abroad as compared to $15 \%$ for Germany, $26 \%$ for Japan, and 7\% for the US. Since the foreign extension of patent applications is usually reserved for the most valuable inventions ${ }^{\mathrm{xi}}$, this reinforces the hypothesis that the value of the average Chinese patented invention is quite low. This is in line with the low percentage of revenue that Chinese firms devote to R\&D in comparison to western companies, as indicated by Table 5 , which gives R\&D expenditure for a selection of big PV cell and module manufacturers.

Table 5. R\&D expenditure in some major cell and module companies.

\begin{tabular}{|l|c|c|l|}
\hline Companies & $\begin{array}{c}\text { Country of } \\
\text { origin }\end{array}$ & $\begin{array}{c}\text { R\&D intensity } \\
(\% \text { of } 2008 \text { turnover })\end{array}$ & \multicolumn{1}{|c|}{ Segments } \\
\hline Schott Solar & DE+US & $5.0 \%$ & Cells \\
\hline Q-cells & DE & $2.0 \%$ & Cells \\
\hline SunPower & US + PH & $1.7 \%$ & Cells+ modules \\
\hline Solar World & DE & $1.4 \%$ & Cells \\
\hline
\end{tabular}




\begin{tabular}{|l|c|c|l|}
\hline Suntech & CN & $0.8 \%$ & Cells + modules \\
\hline China Sunergy & $\mathrm{CN}$ & $0.5 \%$ & Cells + modules \\
\hline Solarfun & $\mathrm{CN}$ & $0.4 \%$ & $\begin{array}{l}\text { Cells + modules } \\
+ \text { ingots }+ \text { wafers }\end{array}$ \\
\hline Trina Solar & $\mathrm{CN}$ & $0.4 \%$ & $\begin{array}{l}\text { Cells }+ \text { modules } \\
\text { +ingots + wafers }\end{array}$ \\
\hline
\end{tabular}

Source Source: company annual reports

Chinese firms then have a higher propensity to patent than their foreign competitors - they file more patent applications for an equivalent innovation output. Our field investigations in China confirm that local companies patent minor inventions intensively. The reason is not to protect the inventions - critical inventions are usually kept secret - but to send a signal to public authorities. In particular, the allocation of public subsidies by the National Development and Reform Commission (NDRC) is significantly influenced by the quantity of patents.

However, concluding from this low patent value that Chinese firms don't innovate could be misleading. As the interviews suggested that Chinese innovation focuses more on process, which is often not carried out in specific R\&D departments but directly on the production lines, and protected by secrecy rather than patenting.

\subsection{Innovation in silicon production, ingot and wafer manufacturing}

We have seen that China's patenting performance in upstream segments is impressive. This is particularly true for silicon, with $37 \%$ of the world's patented inventions as shown by Figure 6 , this results from a specific effort initiated in 2002. 
Figure 6 Share of China in world innovation in each segment of the PV industry

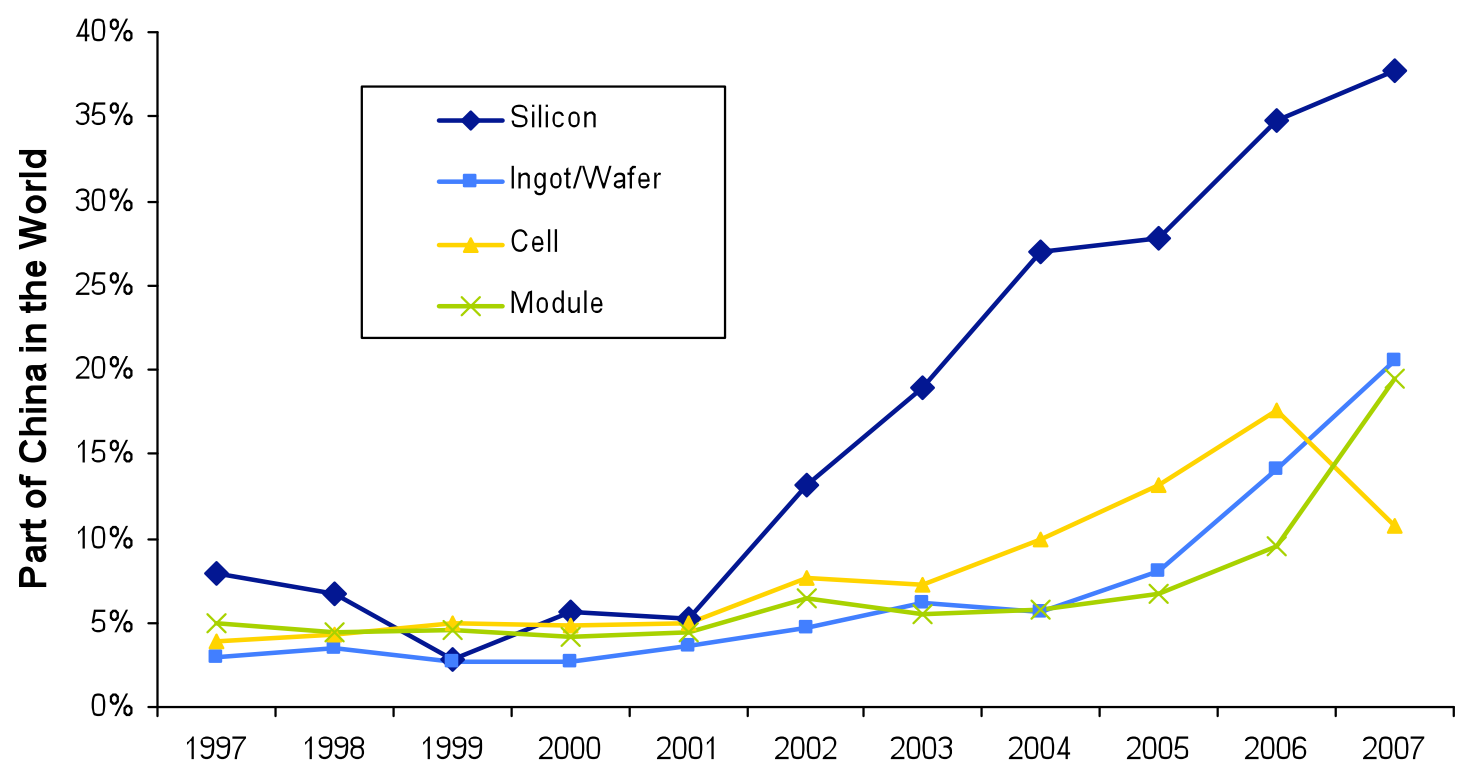

Source Authors' calculation

Why is it so? China only accounts for $2.5 \%$ of 2007 world production, but the government has voiced its ambition to dramatically rise production capacities in the coming years. Domestic production of purified silicon has already grown 16.5 times from 2007 to 2008 (from 1,100 to 18,000T, REDP 2008).

The Chinese patenting activity in silicon technology is related to this strategic objective. Besides capital investment in production facilities, the main barrier to entry in the silicon feedstock market is technological. The purification of metallurgical grade silicon into electronical grade silicon is based on the Siemens process - the principles of which have been public information for decades. The key to purifying silicon at reasonable cost, however, is in the efficiency of the silicon purification process, which requires precisely controlling the parameters of all the chemical reactions. Major western and Japanese silicon producers have developed advanced know-how in this domain, which they usually keep secret. In this context, the creation of a competitive branch of the Chinese PV industry in the silicon segment hinges on its domestic R\&D effort to develop economically efficient refining processes. These efforts are chiefly funded by public authorities. Private patents represent less than $40 \%$ of total Chinese patented innovation, against around $85 \%$ in industrialized countries. 
To summarize, the Chinese weight in patent applications in silicon purification, far from proving a technological leadership, actually denotes a massive domestic effort to break a technological lock in a strategic segment where the Chinese industry is still dependent on a small number of foreign suppliers.

\section{Conclusion}

China has become in just a few years a major player of the global PV industry. In this paper, we have tried to understand how this has occurred, and in particular, how Chinese producers get access to the technologies and skills necessary to produce PV systems.

A first finding is that the economic importance of Chinese producers should not be overestimated. They are mostly active in downstream segments of the PV production chain - cell production and module assembling - where barriers to entry are low, competition is tough and profit margins are thin. Western companies continue to lead upstream markets - in silicon purification, ingot and wafer manufacturing - where technological skills are key assets. This global division of labour between China and developed countries in this industry is observed in many industrial sectors. Note that China has ambitious plans of new production capacities in upstream segments, in particular silicon production, in the coming years.

China has acquired the technologies to produce cells and modules through two main channels: the purchase of manufacturing equipment - in particular turnkey production lines - on a competitive international market and the recruitment of skilled Chinese entrepreneurs from the Chinese Diaspora who have managed to build pioneer PV firms, exploiting China's comparative advantage of cheap labour and energy in PV cells and module segments. In contrast, the lack of competitive supply of production equipment appears to have been a significant barrier to the development of Chinese firms in the upstream silicon segment.

Foreign Direct Investments, mainly through the establishment of joint-ventures with western partners, are another potential channel for importing technologies. They are very significant in the Chinese PV industry but they are quite recent and they do not involve pioneering Chinese companies. This suggests that they have played a minor role in the emergence of the industry. The trade of intellectual property rights such as licensing has played no role. More generally, the existence of property rights has not impeded the emergence of the Chinese industry. 
As measured by patent statistics, the innovative performance of China denotes a policy-driven effort to catch up rather than a dynamism of local companies. Chinese producers of cells and modules invest less in R\&D than their competitors in Japan and Western countries, and consequently file fewer patents that are of lesser value. By contrast, the important share of China in world patents in the silicon, ingot and wafer segments is largely accounted for by public research institutions, denoting an effort to break the technology barriers preventing firms from entering these segments. Although it is too early to predict a success, this trend highlights the ability of the Chinese public authorities to intervene selectively when the market fails to generate technology transfers.

In terms of policy implications, our research suggests that, in order to diffuse clean technologies to emerging economies, a key issue is the need to create an attractive environment for investment and international trade. In this respect, the focus of international discussions on intellectual property seems misplaced. Of course, one should be very cautious when generalizing results obtained from one particular sector. But this is in line with other works by Barton (2007) and by Kirkegaard et al. (2009) who studied solar, biofuel and wind technologies. In fact, the underlying reason is the same: the competition is sufficient in these sectors to prevent a single company from creating a lock on the technology with patents.

Here at the end of this paper, it is also possible to address a more fundamental question: what is the rationale for promoting the transfer of production technologies to the South, from a general interest perspective? The example of the PV sector shows that this transfer does not necessarily induce GHG emissions abatement in emerging economies: China has successfully entered the PV market without deploying panels at home. In fact, the real justification is that the transfer of technology is necessary in order to transfer production capacities to emerging economies and this relocation can decrease production costs and prices through fiercer competition, as is true in many other industrial sectors. Ultimately, technology transfers will reduce the cost of mitigating greenhouse gas emissions.

From the perspective of industrialized countries, this is disturbing. Of course, they benefit from these cost reductions, as demonstrated by the commercial success of Chinese panels in Spain and Germany. But while they drive the demand trough costly incentive policies, their companies face tougher competitors and lose market shares - again, see the situation of the German PV company Q-Cells which have faced severe difficulties in the last years. 


\section{References}

Barton, J., 2007. Intellectual Property and Access to Clean Energy Technologies in Developing Countries. An Analysis of Solar Photovoltaic, Biofuel and Wind Technologies. ICTSD Programme on Trade and Environment, Issue Paper No. 2

Cohen, W.M., Nelson, R.R., Walsh, J.P., 2000. Protecting their Intellectual Assets: Appropriability Conditions and Why U.S. Manufacturing Firms Patent (or Not). NBER Working Paper no. 7552

Dechezleprêtre, A., Glachant, M., and Ménière, Y., 2010. What Drives the International Transfer of Climate Change Mitigation Technologies? Empirical Evidence from Patent Data. CERNA Working Paper

EPIA (European Photovoltaic Industry Association), 2009. Global market outlook for photovoltaics until 2013

EPIA (European Photovoltaic Industry Association), 2010. Global market outlook for photovoltaics until 2014

European Commission, DG Joint Research Center, PV status report 2005, 2008 and 2009

IEA (International Energy Agency), 2009. Trends in photovoltaic applications, Survey report of selected IEA countries between 1992 and 2008

Kirkegaard, J.F., Hanemann, T., and Weischer, L., 2009. It Should Be a Breeze: Harnessing the Potential of Open Trade and Investment Flows in the Wind Energy Industry. Working Paper

Marigo, N., 2007. The Chinese Silicon Photovoltaic Industry and Market: A Critical Review of Trends and Outlook, Progress in Photovoltaic: Research and application, 2007; 15:143-162 10.1002/pip.716

McKinsey, 2008. The economics of solar power 
REDP (China Renewable Energy Development Project), 2008. Report on the development of the photovoltaic industry in China (2008)

REN21 (Renewable Energy Policy Network for the 21st Century), 2008. Renewables 2007 Global Status Report

Ruoss, D., 2007. Global Photovoltaics Business and PV in Malaysia, Envision report

Yanga, H., He Wanga, Huacong Yub, Jianping Xib, Rongqiang Cui, Guangde Chen, 2003. Status of photovoltaic industry in China, Energy Policy 31 (2003) 703-707

Winegarner, R. M., 2009. Report 1 Silicon Industry 2008, A comprehensive report on the use of silicon wafers, silicon ingot, and polysilicon in the semiconductor industry on a fab by fab basis, Sage Concepts 
Appendices

Appendice 1: List of firms where interviews have been carried out

\begin{tabular}{|c|c|c|c|c|c|c|}
\hline Firms & $\begin{array}{c}\mathrm{Nb} \\
\text { Employees }\end{array}$ & Activity & $\begin{array}{c}\text { Creation } \\
\text { Year }\end{array}$ & $\begin{array}{l}\text { Turnover } \\
\text { (Millions } \\
\text { of USD) }\end{array}$ & $\begin{array}{l}2008 \text { cell } \\
\text { production }\end{array}$ & $\begin{array}{c}\text { World } \\
\text { rank }\end{array}$ \\
\hline Suntech & 8000 & cell+Module & 2001 & $278 \mathrm{M}$ & 1000 & 3 \\
\hline TRINA Solar & 5200 & ingot + wafer + cell + modules & 1997 & $150 \mathrm{M}$ & 450 & 11 \\
\hline Solarfun Power & 1500 & ingot + wafer + cell + modules & 2004 & $576 \mathrm{M}$ & 200 & 12 \\
\hline China Sunergy & & & & & & \\
\hline (CEEG) & 5000 & ingot + wafer + cell + modules & 1990 & 149.5 & 111 & 20 \\
\hline Topsolar & 800 & cell+Module & 2002 & 175 & 48 & 38 \\
\hline ST Solar & 125 & modules & 2003 & n.a. & 25 & $>50$ \\
\hline Universal Solar & 120 & modules & 2003 & 53 & 25 & $>50$ \\
\hline Chaori Solar & 1100 & ingot + wafer + cell + modules & 2001 & n.a. & 22.5 & $>50$ \\
\hline Solar Energy & & & & & & \\
\hline (SSEC) & 560 & ingot + wafer + cell + modules & 2000 & n.a. & 20 & $>50$ \\
\hline University & & & & & & \\
\hline
\end{tabular}

Shiaotong University, Institute of Solar Energy

Source: Interviews, ENF website, firms' websites, and PV report 2009

Appendice 2 Methodology: The patent as an indicator of the innovation and technology transfer

Innovation cannot be measured directly like other variables. Several indicators have therefore been developed to measure it. One is the measure of the input ( $R \& D$ expenditure, number of staff in the R\&D department), but such information is difficult to find, is aggregated, and only measures the input while the output can be preferable (Dechezleprêtre et al. 2010). Measure of the output can be done by studying the data on patents. This indicator has many advantages as it allows to have disaggregated information by technology, and also gives information about where the innovation is patented, which is necessary to study technology transfer. 
As represented in Figure 6, if a person (or firm) innovates, it can decide to patent the invention in one or several countries, which will give him the exclusive right to commercially exploit that invention in those countries. In a single country, one or several patents can be granted to protect the invention according to its importance and the characteristics of the patent office of the country. The heterogeneity of national patent laws makes it difficult to make reliable crosscountry comparisons. We deal with this classical problem by counting patent families, i.e. the set of patents granted for the invention in the different countries.

Figure 7 Schema of a patent family

Patent family of invention i

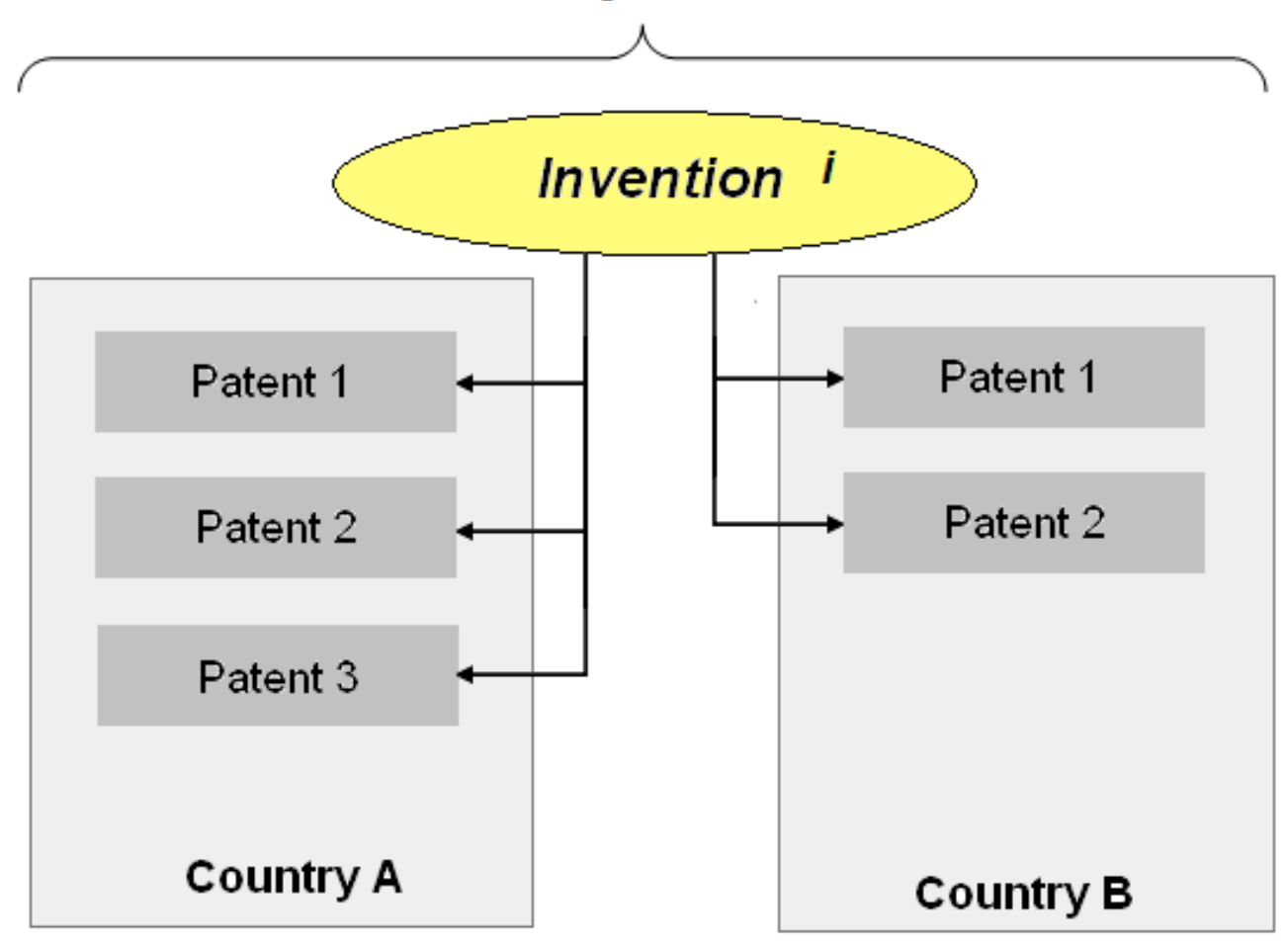

Patent breadth of country $A=2 / 3$ patent breadth of country $B$

Following the method developed by Dechezleprêtre et al. (2010), the indicator used to measure the quantity of innovation or technology diffusion process is then based on the number of families, that is to say the number of inventions.

However, a variable quantity of innovation can be embedded in those inventions. To take that into consideration, we use as a proxy of the "size" of the invention the number of patents granted in one country for this invention multiplied by the average patent breath in this country. The patent breadth of one country is the average "size" of the patents registered in the patent office of 
the country. In our example, the same invention has been protected by three patents in country A, while only 2 in country B. That it to say that with this single case, patent breadth in country A is $2 / 3$ of that of country B. In our study, countries patent breadths have been computed using the US benchmark: for each countries "c", we kept only the patent families where patents have been at least granted in the US and in country c, and the patent breadth of country c is then defined as

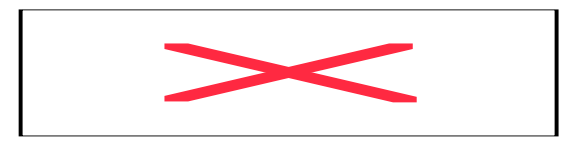

If the invention $i$ has been patented in only one country (most of the case), the "size" of this invention (quantity of innovation embedded the invention) is then approximated by:

$$
\text { Size }_{\mathrm{i}}=\mathrm{NbPatent}_{\mathrm{i}, \mathrm{c}} * \text { PatentBreadth }_{\mathrm{c}}
$$

Where $\mathrm{NbPatent}_{\mathrm{i}, \mathrm{c}}$ is the number of patents granted for invention $\mathrm{i}$ in country $\mathrm{c}$.

If the invention has been patented in several countries, the size of the invention is then approximated by the average of (2), that is:

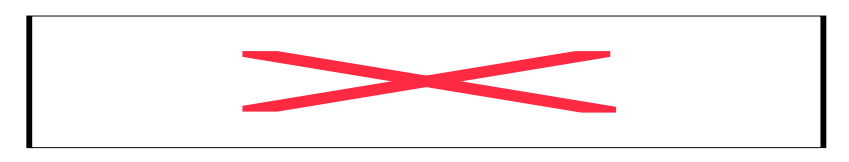

Having this information, one can then approximate the innovation done by one country $\mathrm{c}$ in one year $\mathrm{y}$ in one segment $\mathrm{s}$ by summing the sizes of all the inventions done by this country, this year, in this segment $(i \in(c, y, s))$

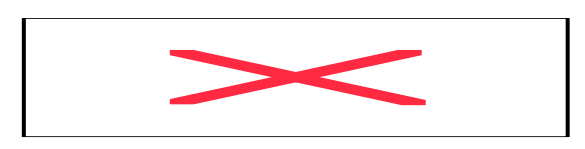

The technology transfer can be approximated the same way by keeping only the inventions that have been patented in a chosen country.

\section{Limits of the indicator}

Inventions do not have uniformly equal value, but this value can be approximated by the percentage of international families (meaning a patent that has been granted in at least two countries). Indeed, after the first patent application, the applicant has two years to patent the 
invention in other countries. The first application can only be an option for future commercial application while if the invention is patented in other countries, it proves that the applicant really shows some commercial interest in it. There is then a big gap in value between a patent that has been granted only in one country, and patents that have been granted in two or more countries.

A second, more difficult methodological issue is due to the fact that not all innovations are patented in practice. This is especially true for process innovations, which are often kept secret (Cohen et al., 2000). Since an important part of PV innovations concern manufacturing processes, this implies that our patent indicators probably do not account for all inventions.

\section{Database used}

We built our dataset by downloading patent information from the espacenet website ${ }^{\text {xii }}$. For this purpose, we choose research criteria designed for all PV segments in order to obtain the biggest part of the relevant patents (corresponding to the technology) while having as few irrelevant patents as possible. Not having every patents doesn't matter as the sample is still representative, but having too much irrelevant patents is more problematic. This can be limited by using proper research criteria. Here are the research criteria used:

\begin{tabular}{|c|c|}
\hline Keyword(s) in title or abstract: & $\begin{array}{c}\text { International Patent Classification (IPC) } \\
\text { code: }\end{array}$ \\
\hline \multicolumn{2}{|c|}{ Silicon purification } \\
\hline Silicon & C01B33 not C01B33/02 \\
\hline \multicolumn{2}{|c|}{ Ingot } \\
\hline Silicon & C01B33/02 OR C30B \\
\hline \multicolumn{2}{|r|}{ (2) } \\
\hline $\begin{array}{l}\text { silicon wafer not semiconductor? } \\
\text { wafer }\end{array}$ & $\begin{array}{c}\text { H01L21 } \\
\text { B24 OR B28 }\end{array}$ \\
\hline \multicolumn{2}{|l|}{ (a } \\
\hline (solar cell?) or photovoltaic not modu & H01L \\
\hline \multicolumn{2}{|c|}{ Module } \\
\hline PV or solar or photovoltaic and modu & H01L \\
\hline
\end{tabular}

We note that the fact that we obtain a different proportion of the patents really granted in each segment doesn't matter, as no absolute comparison will be done for the reasons explained in the 
previous section. We obtained 79,642 patents, published before 2010, covering the PV industry from silicon purification to module assembling.

${ }^{\mathrm{i}}$ The Bali Road Map mentions for instance technology diffusion as a strategic objective.

${ }^{\text {ii }}$ As the Ad Hoc Working Group on Long-term Cooperative Action under the Convention (AWG-LCA) created in 2009 under the UNFCCC (see http://unfccc.int/meetings/items/4381.php)

iii You can refer to Annex 1 for more information concerning interviewed actors.

iv The monosilicon conversion leads to more efficient PV cells, but has large power consumption and is thus more expensive than the polysilicon process. Dopant impurity atoms such as boron or phosphorus can be added to the molten silicon in precise amounts in order to dope the silicon, thus changing it into n-type or p-type silicon.

${ }^{v}$ The HHI is defined as the sum of the squares of the market shares of the largest firms within the industry, where the market shares are expressed as fractions. The result is proportional to the average market share, weighted by market share. As such, it can range from 0 to 1, moving from a huge number of very small firms to a single monopolistic producer.

${ }^{\mathrm{vi}}$ According to Chinese Firms that we interviewed, the labour represents $1-2 \%$ of the total cost in China in module production segment; in developed countries it represents $5-10 \%$.

vii http://www.enf.cn/ is an online Solar company database.

viii The number of equipment providers is the only, admittedly rough, indicator available to measure the country market shares as turnover data are seldom available.

ix Information obtained on the companies' website: http://www.suntech-power.com; http://www.trinasolar.com ; http://www.solarfun-power.com.

${ }^{\mathrm{x}}$ You can refer to annex 2 for more information concerning the methodology used.

${ }^{x i}$ For further details, see annex 2, Limits of the indicator

${ }^{\mathrm{xii}}$ http://ep.espacenet.com is a free online service developed by the European Patent Office for searching information on patent and patent application. 